\title{
POSSIBLE MOLECULAR MECHANISMS AND PATHWAYS INVOLVED IN BH3 MIMETIC ACTIVITY OF ALPHA-LIPOIC ACID ON HUMAN COLON CANCER CELL LINE
}

\author{
IVANA DAMNJANOVIC ${ }^{1} *$, GORDANA KOCIC ${ }^{2}$, STEVO NAJMAN $^{3}$, SANJA STOJANOVIC ${ }^{3}$, \\ KATARINA TOMOVIC ${ }^{1}$, BUDIMIR ILIC ${ }^{4}$, ANDREJ VELJKOVIC ${ }^{2}$, SRDJAN PESIC ${ }^{5}$, ANDRIJA \\ SMELCEROVIC ${ }^{1,4}$
}

${ }^{1}$ Department of Pharmacy, Faculty of Medicine, University of Nis, Blvd. Dr Zorana Djindjica 81, 1800 Nis, Serbia

${ }^{2}$ Department of Biochemistry, Faculty of Medicine, University of Nis, Blvd. Dr Zorana Djindjica 81, 18000 Nis, Serbia

${ }^{3}$ Department for Cell and Tissue Engineering, Institute of Biology and Human Genetics, Faculty of Medicine, University of Nis, Blvd. Dr Zorana Djindjica 81, 18000 Nis, Serbia

${ }^{4}$ Department of Chemistry, Faculty of Medicine, University of Nis, Blvd. Dr Zorana Djindjica 81, 18000 Nis, Serbia

${ }^{5}$ Department of Pharmacology, Faculty of Medicine, University of Nis, Blvd. Dr Zorana Djindjica 81, 18000 Nis, Serbia

*corresponding author: ivana.damnjanovic@medfak.ni.ac.rs

Manuscript received: March 2018

\begin{abstract}
Alpha-lipoic acid (ALA), a naturally-occurring antioxidant, inhibits proliferation and induces apoptosis in various cancer cell lines without effects on normal non-transformed cells. The aim of this study was to examine the effects of alpha-lipoic acid (ALA), alone and combined with 5-fluorouracil (5-FU), on Bcl-2/Bax expression in human colon cancer Caco-2 cell line as well as to investigate possible molecular mechanisms and pathways involved in ALA-mediated effects. In the present study ALA and 5-FU showed a tendency to decrease Bcl-2 and increase Bax expression. ALA exerted higher inhibitory effects on Bcl-2 expression, while the significant increase of Bax expression was shown after the treatment with the combination of ALA and 5-FU. The binding modes of ALA and 5-FU with both targets were shown to be closely similar, and some interactions the same like those of known BH3 mimetics. Thus, ALA may be considered as potential BH3 mimetic. Additionally, with in silico calculated physico-chemical properties taken into account, it was confirmed that ALA may easily be delivered to its intracellular and membrane targets.
\end{abstract}

\section{Rezumat}

Acidul alfa-lipoic (ALA), un antioxidant natural, inhibă proliferarea și induce apoptoza la nivelul diferitelor linii celulare canceroase, făă efect asupra celulelor normale netransformate. Scopul acestui studiu a fost de a evalua efectele acidului alfalipoic (ALA), singur și combinat cu 5-fluorouracil (5-FU), asupra exprimării Bcl-2 / Bax în linia celulară Caco-2, de origine din colonul uman, ca să investigheze posibilele mecanisme moleculare și căile implicate în efectele mediate de ALA.În studiul de față ALA și 5-FU au arătat o tendință de scădere a Bcl-2 și creșterea expresiei Bax. ALA a exercitat un efect inhibitor mai mare asupra exprimării Bcl-2, în timp ce creșterea semnificativă a expresiei Bax a fost demonstrată după tratamentul combinat ALA și 5-FU. Modelele de legare a ALA și 5-FU de ambele ținte moleculare s-au dovedit a fi foarte apropiate, iar unele interacțiuni sunt identice cu cele cunoscute pentru mimeticele BH3. Astfel, ALA poate fi considerat ca potențial mimetic BH3. În plus, proprietățile fizico-chimice evaluate in silico au confirmat că ALA are un tropism deosebit pentru țintele intracelulare și membranare ale acțiunii sale.

Keywords: alpha-lipoic acid, BH3 mimetic, colon cancer, molecular mechanisms

\section{Introduction}

Alpha-lipoic acid (ALA), a small dithiol molecule derived from octanoic acid, may act as a powerful micronutrient with diverse pharmacological and antioxidant properties [1]. This naturally-occurring antioxidant, known as a vitamin, co-factor of some mitochondrial enzymes (pyruvate dehydrogenase, $\alpha$ ketoglutarate dehydrogenase, glycine decarboxylase), potent free radical scavenger and drug candidate, may be de novo synthesized in small amounts by animals and humans $[2,3]$. It can also be absorbed from dietary sources such as red meat, potatoes and may be present in wheat and, to a lesser degree, in fruits and vegetables $[4,5]$. Namely, high ALA contents (0.55 to $2.36 \mathrm{ppm}$ ) are present in food of animal origin (mainly in liver and muscles), whereas plants contain very little $(0.09 \mathrm{ppm})$ or no detectable ALA [6]. It has been used like a dietary supplement in the prevention or treatment of stroke, diabetes, neurodegenerative and hepatic disorders [3]. Moreover, it has been reported that ALA inhibits proliferation and induces apoptosis in various cancer cell lines including human lung epithelial cancer NCI-H460 cells [7], human cervical carcinoma HeLa S3 cells [8], 
ovarian carcinoma cell lines IGROV1 and IGROV1R10 [9], SMMC-7721 human hepatoma cell line [10], MDA-MB-231 breast cancer cells [11], T24 human bladder cancer cell line [12] and human promyelocytic HL-60 cells [3], without effects on normal nontransformed cells [7]. The cytotoxicity of ALA at millimolar concentrations was shown on SW620 human colon carcinoma cells as well as the enhancement of this effect in a synergistic manner in the combination with ascorbate [13]. It has been determined that ALA is able to effectively induce apoptosis in human colon cancer HT-29 cells via increased ROS (reactive oxygen species) production in mitochondria [14]. ALA has been reported to induce cell death in HT-29 and Caco- 2 cell lines mediated by the activation of caspase-9, -3 and -7 , and potentiate the cytotoxicity of 5-fluorouracil (5-FU) in these cells [15]. ALA may be considered as potential novel drug candidate for cancer therapy, but mechanisms of its chemopreventive effects need to be better clarified.

Continuing research on chemopreventive potential of ALA, after testing its effects alone or in combination with 5-FU or cisplatin on the proliferation of colon cancer cell lines and proved anti-proliferative activity [8], the aim of this study was to assess the effects of ALA, alone and combined with 5-FU, on Bcl-2/Bax expression in human colon cancer Caco-2 cell line as well as to investigate possible molecular mechanisms and pathways involved in ALA-mediated effects. Molecular docking studies were performed to gain an insight into the binding modes of possible interactions of ALA and 5-FU with Bcl-2 and Bax proteins as checkpoints of intrinsic apoptotic pathway.

Additionally, an in silico study using Molinspiration tool [16] was performed in order to gain a better insight into the physico-chemical properties of ALA.

\section{Materials and Methods}

Chemicals

Alpha-lipoic acid (ALA) and 5-fluorouracil (5-FU) were purchased for experiments as follows: ALA (Berlition ED 300, Berlin-Chemie, Germany, $300 \mathrm{mg} / 12 \mathrm{~mL}$ ) and 5-FU (Fluorouracil Teva, Pharmachemie BV Netherlands, $50 \mathrm{mg} / \mathrm{mL}$ ). DMEM (Dulbecco's Modified Eagle Medium), FBS (Foetal Bovine Serum), antibiotic/ antimycotic solution, L-glutamine and Trypsin-EDTA solution were purchased from PAA Laboratories (PAA Laboratories, Austria). Trypan blue for cell staining was purchased from Invitrogen. Primary anti-Bcl-2 and anti-Bax antibodies and secondary antibodies were purchased from Santa Cruz Biotechnology (Santa Cruz, CA, USA). Examined cytostatic drug 5-FU is used in the treatment of colon carcinoma according to the protocol [17].

Cell line

In this study we used Caco- 2 cell line (human colon cancer cells) which was obtained from ATCC. Cells were cultured in DMEM supplemented with $10 \%$ FBS, $2 \mathrm{mM}$ L-glutamine and antibiotic/antimycotic solution at $37^{\circ} \mathrm{C}$ in an atmosphere with $5 \% \mathrm{CO}_{2}$ and saturated humidity. Replacement of the culture medium was performed every 2 to 3 days.

Treatment of cells

Confluent culture of Caco-2 cells was harvested using Trypsin-EDTA solution, washed in buffer solution and the total number of cells was determined by Trypan blue dye exclusion test. Cells were seeded in 96-well plates (Greiner Bio-One, Germany) at a density of $3 \times 10^{4}$ cells per well and cultured for $24 \mathrm{~h}$ under standard cell culture conditions. After that, the examined compounds, alone or in combination, were added to the cells. ALA and 5-FU were diluted in DMEM and three concentrations of each of these compounds were tested (group 1 - the lowest concentration, group 2 - middle concentration and group 3 - the highest concentration). Final concentrations of the assayed compounds were 10, 100 and $1000 \mu \mathrm{M}$. Combining of ALA and 5-FU was performed using the same concentrations as the following: group 1 with group 1, group 2 with group 2, and group 3 with group 3 in the ratio $1: 1$, so that the effective concentrations of compounds in combinations were twice less than the concentrations of compounds that were applied alone. As control we used cells that were incubated only with completed cell culture medium, DMEM, without the assayed compounds. Cells were incubated with ALA and 5-FU for the next $48 \mathrm{~h}$. After that, the level of Bcl-2 and Bax proteins was measured.

\section{Measurement of Bcl-2 and Bax protein levels}

For determining the levels of Bcl-2 and Bax proteins, the cells were treated as it was described in the section "Treatment of cells". After $48 \mathrm{~h}$ of incubation with the assayed compounds cells were further processed according to the protocol by Kocic et al. [18]. Briefly, the cells were washed with phosphate-buffered saline (PBS), fixed by using 70\% methanol and permeabilized with $0.1 \%$ Triton in PBS. The cells were incubated with the primary anti-Bax and anti-Bcl-2 antibodies, washed three times and incubated with the FITCconjugated secondary antibodies. The mean fluorescence intensity (MFI; logarithmic scale) was determined and analysed on a Victor ${ }^{\mathrm{TM}}$ multiplate reader (Perkin Elmer-Wallace, Wellesley, MA). The presented results were obtained following the subtraction of blank values obtained by the treatment with the secondary antibodies only.

Ligand and receptor preparation and validation of docking protocol

The molecular docking study was performed using MOE 2014.0901 to understand the ligand protein interactions in detail. The X-ray crystallographic structures of $\mathrm{Bcl}-2$ protein complexed with inhibitor (PDB code: 4IEH) and Bax protein complexed with 
FARMACIA, 2019, Vol. 67, 2

activator (PDB code: $2 \mathrm{~K} 7 \mathrm{~W}$ ) were obtained from the Protein Data Bank [19, 20].

Statistical analysis

The data were analysed by the commercially available statistics software package (SPSS for Windows ${ }^{\circledR}$, v. 17.0, Chicago, USA) using the Students' t-test and the ANOVA test. The results are presented as percentage of control. The statistical significance was set to $\mathrm{p}<$ 0.05 .

\section{Results and Discussion}

Figure 1 shows the levels of Bcl-2 and Bax quantitative expression in Caco- 2 cell culture treated with different concentrations of ALA and 5-FU under the given experimental conditions. Both tested compounds showed a tendency to decrease Bcl-2 and increase Bax expression levels, compared with control samples. It was shown that ALA exerts a significant inhibitory effect on Bcl-2 expression at the concentration of $1000 \mu \mathrm{M}$, while the effect of 5-FU at the same concentration was lower. The significant increase of Bax expression was shown after the treatment with 5FU alone and its combination with ALA, especially at the highest tested concentrations of both compounds. Literature data showed that 5-FU-induced apoptosis was accompanied by an increased expression of Bax and Bak without consistent modulation of other Bcl2 family proteins [21].

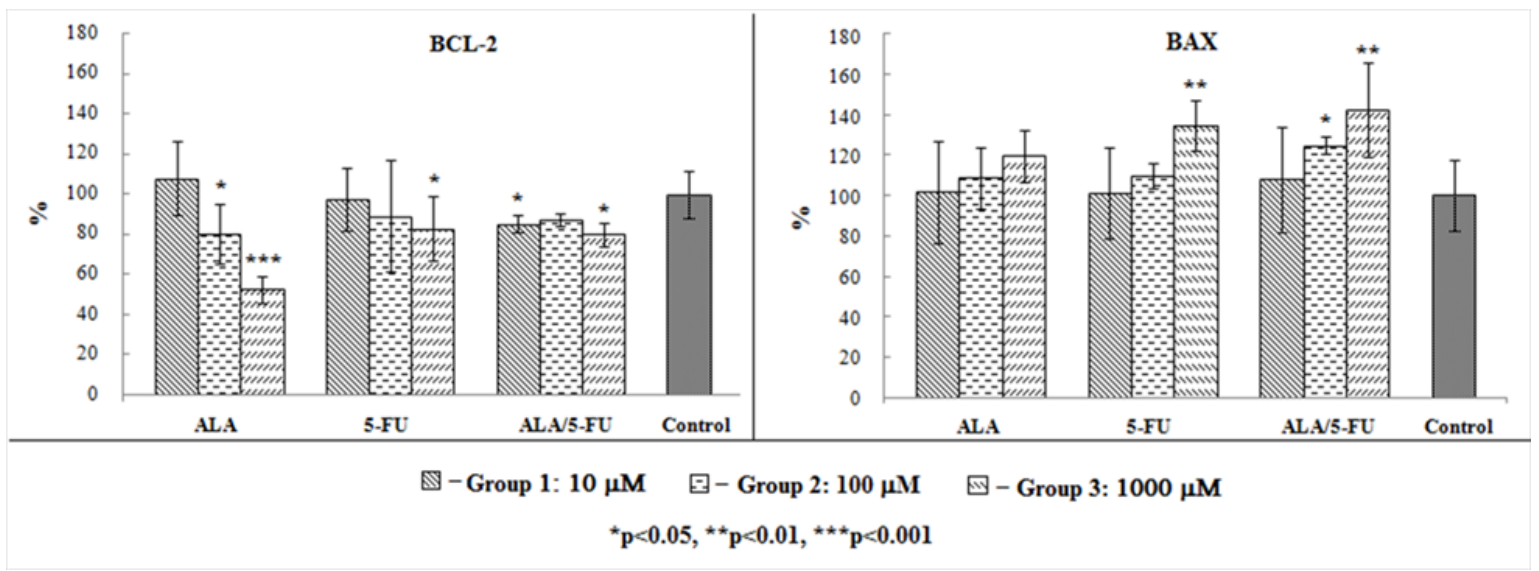

Figure 1.

The effects of ALA, 5-FU and their combination on Bcl-2 and Bax expression in Caco-2 cell culture

The apoptosis has been shown to be a major barrier to cancer cells [22]. Various factors such as Bcl-2 family members play a major role in the intrinsic mitochondrial apoptotic cascade [23]. The members of Bcl-2 family are divided in two main groups, proapoptotic (Bax, Bad, Bak, Bim, Bid, Bik, Noxa, Puma) and antiapoptotic (Bcl-2, Bcl- $\left.\mathrm{x}_{\mathrm{L}}, \mathrm{Bcl}-\mathrm{w}, \mathrm{Mcl}-1\right)$, which are characterized by sharing at least one region of Bcl-2 homology sequence termed BH1-BH4 [24, 25]. The over expression of survival proteins not only contributes to the progression of cancer, but also confers resistance to the therapeutic treatments [25]. Nowadays, the importance of apoptosis, its signalling pathways, checkpoints, mediators and modulators in the pathogenesis and prognosis of colorectal carcinoma is being increasingly recognized. Molecules involved in these pathways represent potential diagnostic markers and therapeutic targets and consequently are the focus of numerous research efforts [26]. Bax/Bcl-2 ratio can act as a rheostat which determines cell susceptibility to apoptosis as well as affects tumour progression and aggressiveness [27]. It has been reported that antiapoptotic Bcl-2 protein plays a role in colorectal precancerous and cancerous lesions [28]. On the other hand, the observed loss of Bcl-2 expression in high-grade tumours may lead to tumour progression to a deregulated state where Bcl-2 would not be required for the cell survival [29]. Indicating the involvement of Bax expression in tumour differentiation and metastatic progression, it has been demonstrated that Bax expression is decreased not only from primary to metastatic but also well/ moderately to poorly differentiated tumours, what leads to more infiltrative growth pattern, more distant metastases, and a weak trend toward poor prognosis [27]. The absence of Bax expression in colorectal cancer cells might induce resistance to apoptosis triggered by different chemotherapeutic agents [30]. The expression of Bcl-2 and Bax has been shown to predict the response to 5-FU based adjuvant therapy in colorectal carcinomas. Namely, the patients with low $\mathrm{Bax} / \mathrm{Bcl}-2$ ratio would benefit from this therapy [31]. Over 50 years have passed since 5-FU was developed, but it still plays a key role in chemotherapeutic regimens in the treatment of breast, colon and pancreatic cancer [32]. Although, 5-FU is a commonly used effective chemotherapeutic agent for treating a wide variety of malignant tumours, the effectiveness of the chemotherapy may be limited because of acquired or intrinsic drug resistance [33]. 
FARMACIA, 2019, Vol. 67, 2

Small BH3-only members, with proapoptotic activity, may be helpful in elucidating alterations in Bax and Bcl-2 expression level in human colorectal carcinoma [27]. Proapoptotic and prosurvival Bcl-2 family proteins contain shared Bcl-2 homology domains $\mathrm{BH} 1-3$, that are involved in the formation of a hydrophobic $\mathrm{BH} 3$ docking groove harbouring binding sites for only $\mathrm{BH} 3$ containing proteins [34]. It has been demonstrated that peptides containing only $\mathrm{BH} 3$ domain of proapoptotic Bcl-2 family members are able to bind and inhibit antiapoptotic proteins [25]. Some BH3-only proteins such as Bim may directly bind to and activate Bax, what leads to the oligomerisation of this proapoptotic protein, permeabilization of the mitochondrial outer membrane, cytochrome c release and activation of caspase- $9,-3$, -6 and $-7[35,36]$. It has been suggested that Bim downregulation is important for tumour-genesis, especially for metastatic ability [36]. Recently, it has been shown that ALA upregulates Bim in ovarian carcinoma cells [9]. Bim phosphorylation by extracellular signal regulated kinase $1 / 2(\mathrm{ERK} 1 / 2)$ promotes its degradation through the proteasome-ubiquitination system [36]. Some preclinical studies have pointed out that Bim induction by inhibition of the ERK pathway plays a key role in apoptosis of oncogeneaddicted solid cancer cells including $B R A F$ - mutant colorectal ones [37]. Moreover, it has been recently reported that $\mathrm{BH} 3$ mimetic ABT-737 may markedly suppress the ERK1/2 phosphorylation levels in a concentration-dependent manner and induce proapoptotic Bim signalling pathway in human oral squamous carcinoma HN22 cells [38]. Contrary to Bim, the phosphorylation of Bcl-2 mediated by ERK2 might be of substantial importance for Bcl-2 stability and cell survival. Bcl-2 dephosphorylation induces its degradation through the proteasome-ubiquitination system and subsequent cell death [39]. It has been documented that ALA induces downregulation of Bcl-2 through its enhanced proteasomal degradation in human lung epithelial cancer cells [7]. The activation of ERK, c-Jun N-terminal kinase (JNK) and p38 kinase in colon tissues was shown to be significantly inhibited by ALA treatment [40]. Thus, by the inhibition of mitogen-activated protein kinase (MAPK)/ ERK, ALA may be considered to upregulate Bim and downregulate Bcl-2 levels in cancer cells. Phosphorylation of Bcl-2 family members has appeared to be a generalized phenomenon that occurs in proapoptotic and antiapoptotic family members [41]. Bax conformational change and its translocation to the mitochondrial membrane is inhibited by phosphorylation in an Akt-dependent manner. After the phosphorylation, Bax effects on the mitochondria are inhibited by remaining its inactive heterodimerized form with antiapoptotic Bcl-2 family members in cytoplasm. Akt (protein kinase B, PKB), also, phosphorylates and inhibits the protease activity of caspase-9 [41-44].
It has been shown on hepatoma and human breast cancer cells that ALA may inhibit Akt activity [10, 11]. In that way, by the inhibition of Akt, ALA may potentiate Bax proapoptotic actions. Recent study on bladder cancer cells represents one more confirmation of the ERK1/2 and Akt downregulation caused by ALA [12]. Generally, the kinase activities of Akt and ERK $1 / 2$ were shown to be significantly upregulated in CD133+ primary colon cancer cells. The clonogenic growth, proliferation and differentiation of these cells was greatly reduced by the inhibition of Akt and ERK1/2 activity. The reported involvement of Akt and MAPK pathways in the tumorigenesis of CD133+ colon cancer cells, suggest that molecules in these two pathways might be potential targets in the future therapy [45]. Moreover, the fate of Caco-2 cells has been shown to be regulated by MAPK and Akt pathways $[46,47]$. Thus, the potential mechanism of proapoptotic effect of ALA concretely in Caco- 2 cells might be explained on the basis of these mentioned pathways.

The activation of intrinsic mitochondrial pathway of apoptosis in cancer cells, mediated by Bcl-2 family members as critical checkpoints, represents the most frequent mechanism of action of anticancer drugs [48]. Antiapoptotic family members are now a major target in the development of novel anticancer drug candidates [49]. Many structurally different Bcl-2 inhibitors and some Bax activators have been discovered in recent years $[50,51]$. A large number of preclinical data suggest that $\mathrm{BH} 3$ mimetics may be highly useful for applying in synergistic therapies with conventional anticancer drugs and radiotherapy [35]. Despite this, the use of $\mathrm{BH} 3$ peptides as therapeutic agents may be limited by their unsatisfactory bioavailability, including poor cellular permeability, solubility and metabolic instability in vivo. It might be feasible to develop agents by "BH3 profiling" with individual prosurvival $\mathrm{Bcl}-2$ family members like targets [52].

The search of protein targets of ALA as well as docking of the binding site is necessary to understand and support its physiological roles and pharmacological effects [2]. Considering the promising biological results in order to evaluate the mode of possible interaction of ALA and 5-FU with Bcl-2 and Bax targets, molecular docking of these compounds and some known Bcl-2 inhibitors and Bax activators was carried out and results were compared. The structures of known inhibitors/activators of these targets are various and were used as starting points to allow the evaluation of the binding modes of ALA and 5-FU. The binding modes of the two assayed compounds resembled those found by the docking study on complexes of Bcl-2 and Bax with their inhibitors and activators, respectively.

Our docking study indicated that the binding mode of two BH3 mimetics with reported high affinity, 
synthesized, orally available ABT-263 (navitoclax) and its synthetic derivative ABT-199, includes the interaction with Arg66 residue of Bcl-2 target. Namely, the interactions of the sulfonyl oxygen of ABT-263 and the carbonyl and sulfonyl oxygen and oxygen of the nitro group of highly specific and potent Bcl2 inhibitor ABT-199 with Arg66 residue were established. Importantly, the interaction of carbonyl oxygen of ALA with Arg66 residue was found in the present study. The common interaction of the binding modes of ALA and 5-FU with Bcl-2 protein was shown to be the arene-hydrogen interaction with Tyr161, which was shown to be involved also in the binding of $\mathrm{BH} 3$ mimetic BI97D6, the new compound of gossypol family with modest binding affinity and reported in vivo antitumor activity. Most of the amino acid residues of the Bcl-2 binding site for ALA and 5-FU overlapped with those involved in the binding pockets for the known and assayed Bcl-2inhibitors (Figure 2).
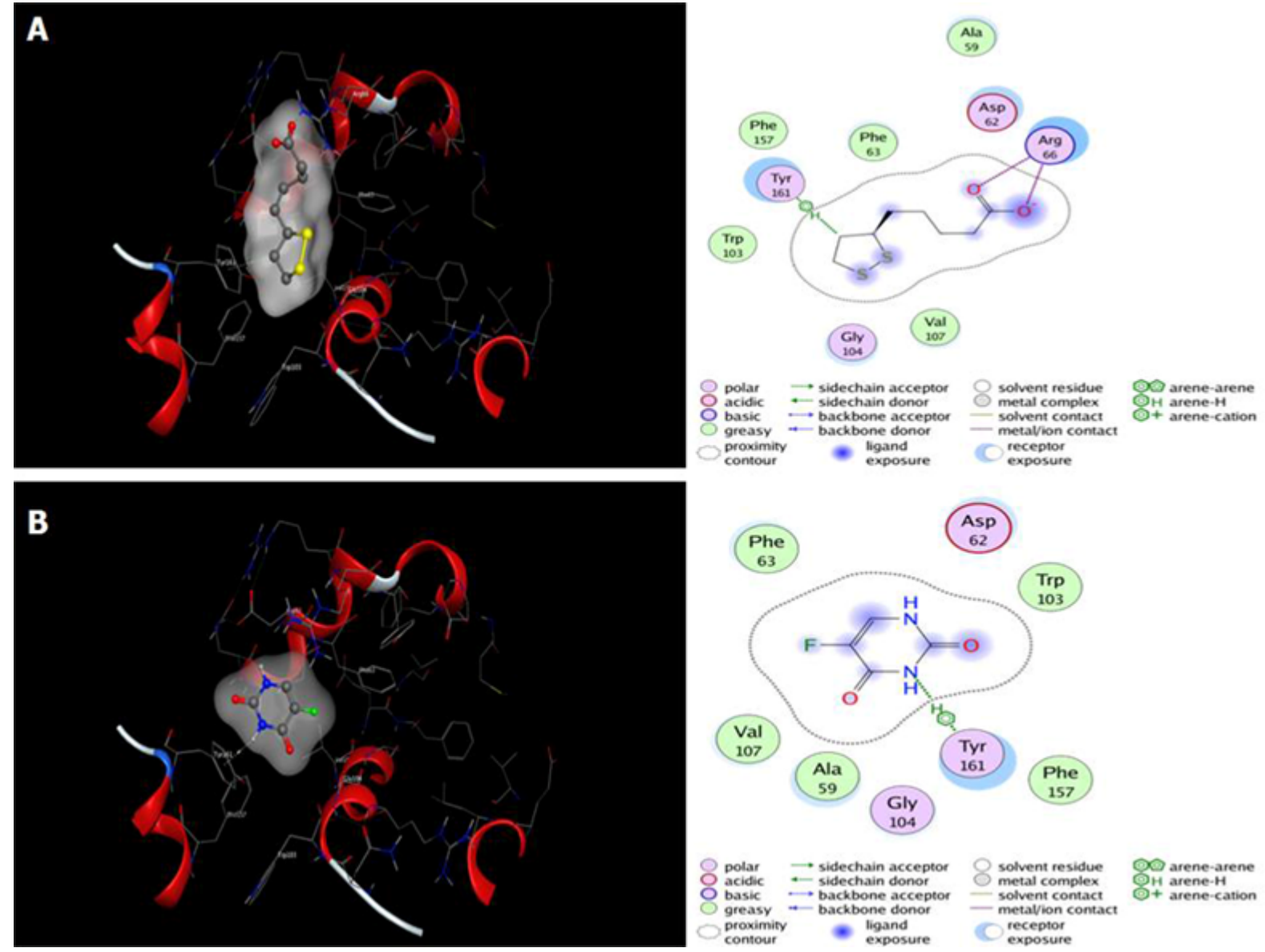

Figure 2.

Docking conformation and 2D representation of ALA (A) and 5-FU (B) interactions in the binding site of Bcl-2 target (PDB code: 4IEH)

Carbonyl oxygen of ALA was found to be responsible also for the binding of Bax target. Namely, the hydrogen bond interaction between carbonyl oxygen of ALA and 5-FU with the backbone structure of Asp53 was found to be involved in their binding for this proapoptotic target. The amino acid residues of the Bax binding site for ALA and 5-FU mainly overlapped with those of the binding cavity for Bax activators BAM-7 and BTC-8, but the arene-hydrogen interactions involved in the binding mode of BAM-7 and BTC-8, were found absent in the binding of ALA and 5-FU (Figure 3).
Molecular docking was performed to evaluate the probable mechanism of proapoptotic action of ALA in cancer cells. It was found that some interactions with the certain amino acid residues of $\mathrm{Bcl}-2$ and $\mathrm{Bax}$ binding sites might play a role in the mechanism of Bcl-2 downregulation and Bax upregulation caused by ALA. Moreover, the binding modes of ALA and 5-FU with both targets were shown to be closely similar, and some interactions the same like those of standard known BH3 mimetics. Therefore, this may be a new possible mechanism of the proapoptotic effect of these compounds. 

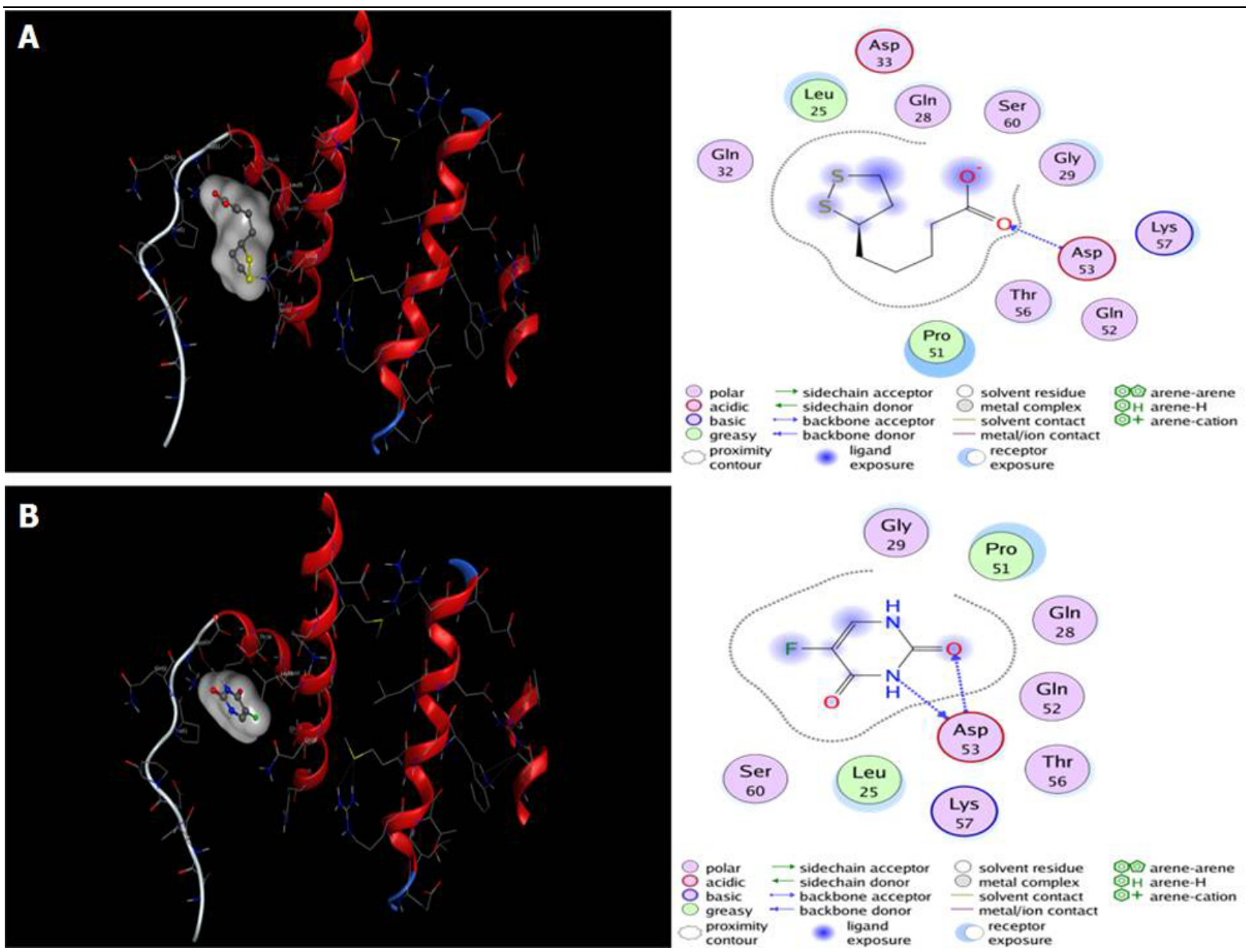

Figure 3.

Docking conformation and 2D representation of ALA (A) and 5-FU (B) interactions in the binding site of Bax target (PDB code: $2 \mathrm{~K} 7 \mathrm{~W}$ )

In order to open new possibilities of this targeted medical application of ALA and to determine the potential advantages with respect to existing agents that influence the apoptotic markers and pathways in cancer cells, the calculated physico-chemical properties of this compound were taken into account. Summarizing the physico-chemical properties, calculated by using Molinspiration tool [16], it was concluded that this compound obeys the Lipinski "Rule of five" and meets all criteria for good solubility, permeability and conformational flexibility. More than one violation of this rule is the critical limit for acceptable druglikeness [53]. It might be concluded that ALA also obey the Veber rules [54] and might be considered to possess the ability to penetrate biological membranes, that is a common requirement for bioavailability. The lipophilicity of compounds is a common property used to estimate the membrane permeability of a molecule. Thus, ALA may easily cross biological membranes, and reach all the compartments of the cell. Therefore, this is one more confirmation that ALA would be easily delivered to the targets inside the cell or on the cell membranes.

Transcription nuclear factor kappa $\mathrm{B}(\mathrm{NF}-\kappa \mathrm{B})$ is present in the cytoplasm and translocates into the nucleus in response to various inflammatory stimuli. It is known that NF- $\kappa \mathrm{B}$ regulates the expression of genes which play a role in the development and progression of cancer such as cell proliferation, migration and apoptosis [55]. Expression of inducible transcription factor NF- $\mathrm{KB}$ and mitochondrial markers may be helpful in predicting clinical outcome and good predictor of cellular response to a given chemotherapeutic agent. As indicated in our previous studies, the inhibition of growth of cancer HeLa and Caco-2 cell lines associated with the inhibition of NF- $\mathrm{BB}$, this powerful transcription factor in the regulation of cell fate might also be one of the potential ways through which an antiproliferative effect of ALA is performed [8].

To determine the chemo-preventive potential and prognostic relevance of biomarkers involved in the apoptotic pathways in colorectal cancer, multiple markers that reflect the apoptotic status should be studied together. According to our results, ALA may be considered as a promising therapeutic agent in colon cancer due to its efficiency and significant chemopreventive potential. An ideal therapeutic agent would specifically target the cancer cells without causing serious cytotoxicity and systemic damage. 
FARMACIA, 2019, Vol. 67, 2

However, in the case of conventional chemotherapeutic agents, the reason of serious adverse effects is the presence of their targets in normal healthy cells. High selective or specific actions with high efficacy are needed for a good drug candidate that would be nontoxic to the patient [38]. The advantage of ALA from this point of view is the evidence that it may inhibit proliferation and induce apoptosis in various cancer cell lines without effect on normal nontransformed cells [7].

\section{Conclusions}

Our findings suggest that the possible mechanism of proapoptotic effect of ALA in human colon cancer cells may be the inhibition of Bcl-2 or the activation of Bax apoptotic checkpoints and regulators. Thus, ALA may be considered as potential BH3 mimetic. Moreover, the possible mechanism may involve the inhibition of ERK1/2 and Akt pathways. The supposed mechanisms may act synergistic in exerting proapoptotic effects of ALA in cancer cells. Considering the physico-chemical properties taken into account, it may be concluded that ALA can be easily delivered to the potential intracellular targets, such as Bcl-2, Bax, ERK1/2, Akt or NF- $\kappa$ B. These findings may be a part of the explanation of possible mechanisms that contribute to the beneficial effects of this readily available dietary supplement in cancer therapy. The observed mechanisms represent a step forward that will be helpful to further investigation. The obtained results are only the beginning of the examination of the possible effects of ALA on cancer chemoprevention and its effects on standard cytostatics. Moreover, further research from different aspects may be useful in the way of clarification of these suggested or some new potential mechanisms of ALA-mediated antiproliferative and proapoptotic effects in the various types of cancer cells.

\section{Acknowledgement}

The study was supported by the Ministry of Education, Science and Technological Development of the Republic of Serbia (Grants TR 31060, III 41017 and OI 172044) and Internal project of the Faculty of Medicine, University of Nis (No 31). The authors would like to thank Chemical Computing Group for providing us the MOE academic license free of cost for this study.

\section{References}

1. Smith AR, Shenvi SV, Widlansky M, Suh JH, Hagen TM, Lipoic acid as a potential therapy for chronic diseases associated with oxidative stress. Curr Med Chem., 2004; 11: 1135-1146.

2. Maldonado-Rojas W, Olivero-Verbel J, Ortega-Zuniga $\mathrm{C}$, Searching of protein targets for alpha lipoic acid. J Braz Chem Soc., 2011; 22: 2250-2259.
3. Selvakumar E, Hsieh T, Regulation of cell cycle transition and induction of apoptosis in HL-60 leukemia cells by lipoic acid: role in cancer prevention and therapy. J Hematol Oncol., 2008; 1: 1-8.

4. Petersen Shay K, Moreau RF, Smith EJ, Smith AR, Hagen TM, Alpha-lipoic acid as a dietary supplement: Molecular mechanisms and therapeutic potential. Biochim Biophys Acta, 2009; 1790: 1149-1160.

5. Bernini R, Crisante F, Merendino N, Molinari R, Soldatelli MC, Velotti F, Synthesis of a novel ester of hydroxytyrosol and $\alpha$-lipoic acid exhibiting an antiproliferative effect on human colon cancer HT29 cells. Eur J Med Chem., 2011; 46: 439-446.

6. Kim DC, Jun DW, Jang EC, Kim SH, Kim EK, Lee SP, Lee KN, Lee HL, Lee OY, Yoon BC, Lipoic acid prevents the changes of intracellular lipid partitioning by free fatty acid. Gut Liver, 2013; 7: 221-227.

7. Moungjaroen J, Nimmannit U, Callery PS, Wang L, Azad N, Lipipun V, Chanvorachote P, Rojanasakul Y, Reactive oxygen species mediate caspase activation and apoptosis induced by lipoic acid in human lung epithelial cancer cells through $\mathrm{Bcl}-2$ down-regulation. J Pharmacol Exp Ther., 2006; 319: 1062-1069.

8. Damnjanovic I, Kocic G, Najman S, Stojanovic S, Stojanovic D, Veljkovic A, Conic I, Langerholc T, Pesic S, Chemopreventive potential of alpha-lipoic acid in the treatment of colon and cervix cancer cell lines. Bratisl Lek Listy., 2014; 115: 611-616.

9. Kafara P, Icard P, Guillamin M, Schwartz L, Lincet H, Lipoic acid decreases Mcl-1, Bcl-xL and up regulates Bim on ovarian carcinoma cells leading to cell death. J Ovarian Res., 2015; 8: 1-13.

10. Shi D, Liu H, Stern JS, Yu P, Liu S, Alpha-lipoic acid induces apoptosis in hepatoma cells via the PTEN/ Akt pathway. FEBS Lett., 2008; 582: 1667-1671.

11. Na MH, Seo EY, Kim WK, Effects of $\alpha$-lipoic acid on cell proliferation and apoptosis in MDA-MB-231 human breast cells. Nutr Res Pract., 2009; 3: 265-271.

12. Yamasaki M, Iwase M, Kawano K, Sakakibara Y, Suiko M, Ikeda M, Nishiyama K, $\alpha$-Lipoic acid suppresses migration and invasion via downregulation of cell surface $\beta 1$-integrin expression in bladder cancer cells. J Clin Biochem Nutr., 2014; 54: 18-25.

13. Casciari JJ, Riordan NH, Schmidt TL, Meng XL, Jackson JA, Riordan HD, Cytotoxicity of ascorbate, lipoic acid, and other antioxidants in hollow fibre in vitro tumours. Brit J Cancer., 2001; 84: 1544-1550.

14. Wenzel U, Nickel A, Daniel H, $\alpha$-lipoic acid induces apoptosis in human colon cancer cells by increasing mitochondrial respiration with a concomitant $\mathrm{O}_{2}$ generation. Apoptosis, 2005; 10: 359-368.

15. Dörsam B, Göder A, Seiwert N, Kaina B, Fahrer J, Lipoic acid induces p53-independent cell death in colorectal cancer cells and potentiates the cytotoxicity of 5-fluorouracil. Arch Toxicol., 2015; 89: 1829-1846.

16. Molinspiration Cheminformatics v2014.11; Molinspiration property engine: www.molinspiration.com.

17. Labianca R, Nordlinger B, Beretta GD, Brouquet A, Cervantes A, Primary colon cancer: ESMO Clinical Practice Guidelines for diagnosis, adjuvant treatment and follow-up. Ann Oncol., 2010; 21: 70-77.

18. Kocic G, Pavlovic R, Najman S, Nikolic G, Sokolovic D, Jevtovic-Stoimenov T, Musovic D, Veljkovic A, Kocic R, Djindjic N, Circulating ribonucleic acids and 
metabolic stress parameters may reflect progression of autoimmune or inflammatory conditions in juvenile type 1 diabetes. Sci World J., 2011; 11: 1496-1508.

19. Touré BB, Miller-Moslin K, Yusuff N, Perez L, Doré M, Joud C, Michael W, Dipietro L, Van Der Plas S, McEwan M, Lenoir F, Hoe M, Karki R, Springer C, Sullivan J, Levine K, Fiorilla C, Xie X, Kulathila R, Herlihy K, Porter D, Visser M, The role of the acidity of N-heteroaryl sulfonamides as inhibitors of Bcl-2 family protein-protein interactions. ACS Med Chem Lett., 2013; 4: 186-190.

20. Gavathiotis E, Suzuki M, Davis ML, Pitter K, Bird GH, Katz SG, Tu HC, Kim H, Cheng N, Tjandra LD, BAX activation is initiated at a novel interaction site. Nature, 2008; 455: 1076-1081.

21. Mirjolet JF, Barberi-Heyob M, Didelot C, Peyrat JP, Abecassis J, Millon R, Merlin JL, Bcl-2/Bax protein ratio predicts 5-fluorouracil sensitivity independently of p53 status. Br J Cancer, 2000; 83: 1380-1386.

22. Hanahan D, Weinberg RA, The hallmarks of cancer. Cell, 2000; 100: 57-70.

23. Ocker M, Höpfner M, Apoptosis-modulating drugs for improved cancer therapy. Eur Surg Res., 2012; 48: $111-120$

24. Thomadaki H, Scorilas A, Bcl-2 family of apoptosisrelated genes: functions and clinical implications in cancer. Crit Rev Clin Lab Sci., 2006; 43: 1-67.

25. Delgado-Soler L, Pinto M, Tanaka-Gil K, RubioMartinez J, Molecular determinants of Bim (BH3) peptide binding to pro-survival proteins. $J$ Chem Inf Model., 2012; 52: 2107-2118.

26. Alcaide J, Funez R, Rueda A, Perez-Ruiz E, Pereda T, Rodrigo I, Coveñas R, Muñoz M, Redondo M, The role and prognostic value of apoptosis in colorectal carcinoma. BMC Clin Pathol., 2013; 13: 1-7.

27. Khodapasand E, Jafarzadeh N, Farrokhi F, Kamalidehghan B, Houshmand M, Is Bax/Bcl-2 ratio considered as a prognostic marker with age and tumor location in colorectal cancer?. Iran Biomed J., 2015; 19: 69-75.

28. Saleh HA, Jackson H, Khatib G, Banerjee M, Correlation of Bcl-2 oncoprotein immunohistochemical expression with proliferation index and histopathologic parameters in colorectal neoplasia. Pathol Oncol Res., 1999; 5: 273-279.

29. Tsamandas AC, Kardamakis D, Petsas T, Zolota V, Vassiliou V, Matatsoris T, Kalofonos CE, Vagianos $\mathrm{CD}$, Scopa CD, Bcl-2, bax and p53 expression in rectal adenocarcinoma. Correlation with classic pathologic prognostic factors and patients' outcome. In Vivo, 2007; 21: 113-118

30. Rashmi R, Kumar S, Karunagaran D, Human colon cancer cells lacking Bax resist curcumin-induced apoptosis and Bax requirement is dispensable with ectopic expression of Smac or downregulation of Bcl-xL. Carcinogenesis, 2005; 26: 713-723.

31. Katkoori VR, Suarez-Cuervo C, Shanmugam C, Jhala NC, Callens T, Messiaen L, Posey J3 ${ }^{\text {rd }}$, Bumpers HL, Meleth S, Grizzle WE, Manne U, Bax expression is a candidate prognostic and predictive marker of colorectal cancer. J Gastrointest Oncol., 2010; 1: 76-89.

32. Xu ZY, Tang JN, Xie HX, Du YA, Huang L, Yu PF, Cheng XD, 5-Fluorouracil chemotherapy of gastric cancer generates residual cells with properties of cancer stem cells. Int J Biol Sci., 2015; 11: 284-294.

33. Uchibori K, Kasamatsu A, Sunaga M, Yokota S, Sakurada T, Kobayashi E, Yoshikawa M, Uzawa K, Ueda S, Tanzawa H, Sato N, Establishment and characterization of two 5-fluorouracil-resistant hepatocellular carcinoma cell lines. Int J Oncol., 2012; 40: 1005-1010.

34. Bodur C, Basaga H, Bcl-2 inhibitors: Emerging drugs in cancer therapy. Curr Med Chem., 2012; 19: 18041820.

35. Kogel D, Exploiting BH3 mimetics for cancer therapy. In: Neuzil J, Pervaiz S, Fulda S, (editors). Mitochondria: The anti-cancer target for the third millennium. Chapter 2. Dordrecht: Springer Science + Business Media; 2014. 39-58.

36. Akiyama T, Dass CR, Choong PFM, Bim-targeted cancer therapy: A link between drug action and underlying molecular changes. Mol Cancer Ther., 2009; 8: 3173-3180.

37. Cragg MS, Jansen ES, Cook M, Harris C, Strasser A, Scott CL, Treatment of B-RAF mutant human tumor cells with a MEK inhibitor requires Bim and is enhanced by a BH3 mimetic. $J$ Clin Invest., 2008; 118: 3651-3659.

38. Shin JA, Kim LH, Lee SJ, Jeong JH, Jung JY, Lee HN, Hong IS, Cho SD, Targeting ERK1/2-Bim signaling cascades by BH3-mimetic ABT-737 as an alternative therapeutic strategy for oral cancer. Oncotarget, 2015; 6: 35667-35683.

39. Breitschopf K, Haendeler J, Malchow P, Zeiher AM, Dimmeler S, Posttranslational modification of Bcl-2 facilitates its proteasome-dependent degradation: Molecular characterization of the involved signaling pathway. Mol Cell Biol., 2000; 20: 1886-1896.

40. Sun J, Zhang H, Guan L, Zhou H, Sun M, Alphalipoic acid attenuates trinitrobenzene sulfonic acidinduced ulcerative colitis in mice. Int J Clin Exp Med., 2015; 8: 358-367.

41. Gardai SJ, Hildeman DA, Frankel SK, Whitlock BB, Courtney FS, Borregaard N, Marrack P, Bratton LD, Henson PM, Phosphorylation of Bax Ser184 by Akt regulates its activity and apoptosis in neutrophils. $J$ Biol Chem., 2004; 279: 21085-21095.

42. Yamaguchi H, Wang HG, The protein kinase PKB/ Akt regulates cell survival and apoptosis by inhibiting Bax conformational change. Oncogene, 2001; 20: 7779-7786.

43. Sadidi M, Lentz SI, Feldman EL, Hydrogen peroxideinduced Akt phosphorylation regulates Bax activation. Biochimie, 2009; 91: 577-585.

44. Tsuruta F, Masuyama N, Gotoh Y, The phosphatidylinositol 3-kinase (PI3K)-Akt pathway suppresses Bax translocation to mitochondria. J Biol Chem., 2002; 277: 14040-14047.

45. Wang YK, Zhu YL, Qiu FM, Zhang T, Chen ZG, Zheng S, Huang J, Activation of Akt and MAPK pathways enhances the tumorigenicity of CD133 primary colon cancer cells. Carcinogenesis, 2010; 31: 1376-1380.

46. Bocca C, Bozzo F, Gabriel L, Miglietta A, Conjugated linoleic acid inhibits Caco-2 cell growth via ERKMAPK signaling pathway. J Nutr Biochem., 2007; 18: 332-340. 
47. Calvo N, Russo de BA, Gentili C, PTH inactivates the AKT survival pathway in the colonic cell line Caco-2. Biochim Biophys Acta., 2010; 1803: 343-351.

48. Danial NN, Korsmeyer SJ, Cell death: critical control points. Cell, 2004; 116: 205-219.

49. Weyhenmeyer B, Murphy AC, Prehn JHM, Murphy $\mathrm{BM}$, Targeting the anti-apoptotic Bcl-2 family members for the treatment of cancer. Exp Oncol., 2012; 34: 192-199.

50. Billard C, BH3 Mimetics: Status of the field and new developments. Mol Cancer Ther., 2013; 12: 1691-1700.

51. Stornaiuolo M, La Regina G, Passacantilli S, Grassia G, Coluccia A, La Pietra V, Giustiniano M, Cassese G, Di Maro S, Brancaccio D, Taliani S, Ialenti A, Silvestri R, Martini C, Novellino E, Marinelli L, Structure-based lead optimization and biological evaluation of BAX direct activators as novel potential anticancer agents. J Med Chem., 2015; 58: 2135-2148.

52. Zhang L, Ming L, Yu J, BH3 mimetics to improve cancer therapy; mechanisms and examples. Drug Resist Updat., 2007; 10: 207-217.

53. Lipinski CA, Lombardo F, Dominy BW, Feeney PJ, Experimental and computational approaches to estimate solubility and permeability in drug discovery and development settings. Adv Drug Deliver Rev., 2012; 64: 4-17.

54. Veber DF, Johnson SR, Cheng HY, Smith BR, Ward $\mathrm{KW}$, Kopple KD, Molecular properties that influence the oral bioavailability of drug candidates. $J$ Med Chem., 2002; 45: 2615-2623.

55. Dolcet X, Llobet D, Pallares J, Matias-Guiu X, NF-kB in development and progression of human cancer. Virchows Arch., 2005; 446: 475-482. 